\title{
Covid-19 and border restriction policies: the dilemma of trans-border truck drivers in East Africa
}

\author{
Calvince Omondi Barack ${ }^{1 *}$, Gerishon Barack Munga ${ }^{2}$ \\ Lecturer of Political Science and International Relations, Maseno University, Kisumu, Kenya ${ }^{1 *}$ \\ Graduate Student of Criminology and Social Order, The University of Nairobi, Nairobi, Kenya ${ }^{2}$ \\ barackcalvince@gmail.com ${ }^{1 *}$, gerishon.munga@gmail.com ${ }^{2}$
}

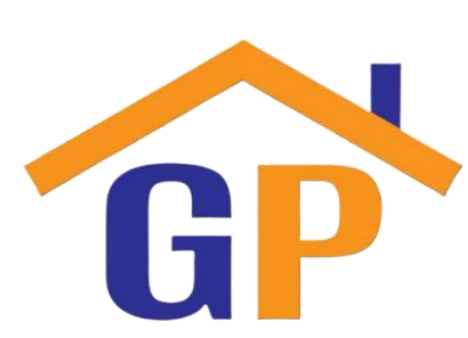

Article History

Received on 2 March 2021

$1^{\text {st }}$ Revision on 30 March 2021

$2^{\text {nd }}$ Revision on 14 April 2021

$3^{\text {rd }}$ Revision on 15 April 2021

Accepted on 16 April 2021

\begin{abstract}
Purpose: The purpose of this paper is to critically assess the challenges that were faced by trans-border truck drivers within the East African Community as a result of the Covid-19 pandemic and its management protocols.
\end{abstract}

Research methodology: While adopting the qualitative research method, this paper has used documents including documented interviews and virtual sources for its data. The data have been analyzed using qualitative content analysis through which themes have been generated for discussions.

Results: The EAC member countries should continue to harmonize their health standardization to enable them to enjoy the pursuit and use of OSBP even during pandemics.

Limitations: This paper, however, is limited to the long-distance truck drivers and the management of Covid-19 within the East African Community and does not cover other aspects of Coordinated Border Management in the region.

Contribution: It provides valuable contributions to the need for harmonization and standardization of operations and health measures within the community as a long-term solution to the challenges of coordinated border management within the community in the face of future pandemics and readiness for the single market regime.

Keywords: Truckers, Coordinated border management, Covid-19, East African Community, Relay driving

How to cite: Barack, C. O., \& Munga, G. B. (2021). Covid-19 and border restriction policies: the dilemma of trans-border truck drivers in East Africa. Journal of Governance and Accountability Studies, $1(1), 55-67$.

\section{Introduction}

The outbreak of Covid-19 towards the end of 2019 in Wuhan China and its subsequent spread throughout the globe has led to untold suffering and loss of lives to humanity. The increase in the negative impact of the Covid-19 led the World Health Organization (WHO) on January 30, 2020, to declare a global emergency (Maria Nicola, et al., 2020: 185). In an attempt to contain the spread of the virus and to "flatten the curve", governments instituted measures that included the shutting down of borders thus, restricting movements of both goods and persons (Maria Nicola, et al., 2020: 185). Given the fragmentation of the production process and the globalization of trade, the shutting down of borders directly threatened transborder trade. The containment measures, therefore, impacted negatively on the trans-border transport system affecting both air and road transports. The human agents involved in the trans-border transport sector bore the greatest challenge since human agents are the greatest carriers of 
Covid-19. This was the case with trans-border truck drivers within the six countries of the East African Community.

Kenya was the first country to register a case of Covid-19 in East Africa on March 12, 2020 (Aluga, 2020). Rwanda, became the second country in the region to register a case of Covid-19 on March 14, 2020. Tanzania followed on March 16, 2020, while Uganda confirmed her first case on March 22, 2020. Similarly, Burundi and South Sudan confirmed their initial cases on March 31, 2020, and April 5, 2020, respectively. The confirmation of the first case within the East African Community (EAC) reshaped the relationship between the member countries as each country attempted to impose measures that would help to protect its citizens from the spread of the virus. However, following the declaration of the state of emergency by WHO over Covid-19, countries begun taking necessary precautions against the possible spread of the virus to their territories. Kenya, for instance, had advised her citizens to keep off non-essential movements to countries that had already recorded cases of Covid-19 on February 13, 2020 (Aluga, 2020: 2). This was followed by the establishment of the National Emergency Response Committee (NERC) on February 28, 2020. This committee cautioned Kenyans against the dangers of Covid-19 and on March 20, 2020, outlined key protocols and a raft of measures that had to be taken to ensure safety with regard to the spread of Covid-19.

The measures taken by Kenya despite having addressed internal issues to do with hygiene and social distancing also addressed the issues of cross-border travels. For instance, the Committee on the Emergency restricted inbound travelers to Kenyans and valid residence permit holders with a mandatory self-quarantine lasting 14 days (Aluga, 2020: 3). In similar vein, the Tanzanian government equally imposed compulsory quarantine for all the people who arrived from most affected countries for 14 days in designated facilities. However, the Tanzanian government did not close her borders but enforced strict testing to flatten the curve (Nsanyiwa, 2020: 15 April). Ugandan government on March 25, 2020, "banned public transport and non-food markets" these measures augmented other measures that had been put in place like paid mandatory quarantine in government-designated hotels (Kabuubi, 2020: 2 April). President Museveni announced new additional measures on March 30, 2020, which included; nighttime curfew, outlawing the use of private vehicles, and severing operations of malls and non-food selling premises for 14 days (Kabuubi, 2020: 2 April). Rwanda used targeted lockdown that was complemented with restricted movements that only allowed "essential services such as healthcare, food shopping or banking and personnel performing such services" (Tasamba, 2020: 22 April). These measures were complemented with the closure of schools including universities as well as churches and mosques (Tasamba, 2020: 22 April). These measures which were taken by the member countries of EAC, directly targeted movements of people in containing the spread of the virus. The governments were careful to permit the movement of foodstuffs and essential services as a way of precaution against breaking the supply chain and the attended negative impact that would come with such collapse in the supply chain.

Thus, the desire to sustain the free flow of essential goods and services behooved the EAC member countries to devise a means of cooperation in ensuring that their borders remained opened while also combating the spread of Covid-19. Subsequently, the EAC Secretariat in its draft of the Covid-19 Plan relied on article 104 of the EAC treaty and "article 7 of the EAC Common Market Protocol", which calls on all member states to put in place measures that facilitate the movement of people, labor, goods, and services in a way that guarantees "the enjoyment of the right of establishment and residence of their citizens within the community" (EAC, 2020: 3). The number of people moving across the borders of the member states had increased significantly from July 2010 with the coming into force of the EAC Common Market Protocol. The EAC secretariat through its joint meeting on March 25, 2020, with ministers responsible for Health and EAC matters, made resolutions that would help in containing the spread of Covid-19 within the community. The EAC Secretariat under its resolution EAC/JMHE/Decision/002 affirmed the need "to minimize cross-border movements of people while facilitating free movement of Goods and Services in the EAC region" (EAC, 2020: 6). This decision 
would help in containing the spread of the virus while keeping the supply of the essential goods and services running within the community.

The EAC also indicated as one of its aim in developing a response to Covid-19 as the need to "Facilitate the movement of goods and services in the region" (EAC Covid-19 Plan 2020: 7). Similarly, the EAC as part of its Covid-19 plan undertook to minimize the impact of Covid-19 on critical socio-economic sectors within the community which include the need to save jobs and income for the individuals within the Micro, Small, and Medium Enterprises (MSMEs) by innovative adaptation and use of locally available resources in staying afloat (EAC Covid-19 Plan 2020: 8). However, as the member countries struggled to contain the pandemic, the aims established by the EAC secretariat increasingly became elusive. For instance, there was almost a week-long strike by Kenyan truck drivers at the Malaba border over accusations of mistreatment and stigmatization by the Ugandan police (Vidija, 2020: 26 May). Consequently, in Rwanda, there was a shortage of supplies of essential goods (Tasamba, 2020: 22 April). The Kenya-Tanzanian border also had its challenges that led to a spike in the price of onions and garlic in Nairobi (Nambi and Chombo, 2020: 21 May). All these challenges being occasioned by restricted cross-border movements and testing requirements for trans-border truck drivers which disrupted the transportation of the essential goods.

The purpose of this paper, therefore, is to examine how the restriction on cross-border movements affected the trans-border truck drivers within the EAC as its first objective. Similarly, it investigates the implications of the restricted cross-border movements during the pandemic and its influence on the onestop border gains that the community had achieved from the time of the coming to force of the Common Market Protocol in 2010. Further, this paper strives to make contributions to the understanding of the factors that inform the smooth and effective operation of OSBP with respect to the East African Community.

\section{Conceptual framework}

The concept of Coordinated Border Management (CBM), has been used as the conceptual framework in analyzing how the EAC member countries handled the cross-border management with regard to the trans-border truck drivers. Borders are conceived as "places of economic and political opportunity for nations and states as well as for a host of other interest groups and agencies, legal and illegal" (O'Dowd, 2002: 24). Borders also serve as markers of sovereignty, however, with CBM borders serve the purpose of facilitation of movements of goods, people, and services. The concept of borders has been altered from time to time. For instance, from the $9 / 11$ attacks in the US, the border concept changed to what has been referred to as "pushed-out" borders (Bowman, 2006: 3). The implementation of "the Container Security Initiative (CSI) and the Customs-Trade Partnership against Terrorism (C-TPAT)" by the US which required the export destinations to share information about the products that are to be exported for a decision by the destination state pushed the borders outside (Polner, 2011: 50). Subsequently, the borders have assumed "a new meaning from trade and security perspectives" beyond the geographical meaning (Polner, 2011: 50).

Despite the new meanings that the border is assuming from different perspectives, globalization has impacted production and consumption patterns. The changes by globalization and liberation have heightened competition among producers demanding faster delivery of goods across borders given the fragmentation of the production process. Consequently, there have been adjustments on supply chains which has increased pressure on the need for improved efficiency and effectiveness by border agencies as cross-border movements of goods continue to expand in volume (Polner, 2011: 50). Border management agencies are also confronted with challenges from the categorization of functions into departments and the need to coordinate these departments to achieve effectiveness in meeting the demands of the prolonged supply chains. The challenges may stem from opaque legislation, lengthy bureaucracy, desire for increased revenues, and calls for ease of operations by the private sector (Doyle, 2011: 12). These challenges place a lot of strain on the border agencies as the call for ease of facilitation 
of movements of people, goods and services continue to grow louder with the fragmentation of production and demands for products and services across borders.

Thus, the pressure for effective management has inspired the coordination of border activities spanning from the mid-1990s under what has been referred to as Coordinated Border Management (CBM) by the World Customs Organization (WCO) (Polner, 2011). The principles of the CBM have their roots in "the International Convention on the Simplification and Harmonization of Customs Procedures (as amended) (the revised Kyoto Convention)" (Polner, 2011: 51). The Kyoto Convention has detailed the key principles of CBM intending to standardize "customs procedures" by introducing the concept of "juxtaposed office" and "joint controls" through its third, sixth, and seventh chapters (Polner, 2011: 51). The convention also provides for standards that promote information sharing among different departments and agencies operating at the border under the "Single Window" Framework as provided within Standards 7.3 and 7.4. (WCO, 2008). The essence of these provisions is to enhance standardization of procedures as well as to concentrate and harmonize border operations in facilitating movements.

The WCO in 2008 developed the "Customs in the 21st Century strategy document" which emphasizes the need to "develop integrated procedures for processing goods at points of entry" as well as the ushering in of "the electronic Single Window" approach that permits sharing of information among the key stakeholders for the ease of cross-border facilitation of the movements of goods and services (WCO, 2008: 7). Subsequently, the coordinated border management system aims at the facilitation of trade and cross-border movement of persons while ensuring border security (WCO, 2009: 5). However, the challenges with the coordination of many agencies at the border have led to calls for the reduction of the actors at the border (Polner, 2011: 54). This call has inspired the establishment of One-Stop Border Posts (OSBP) across national borders.

The OSBP is premised on the desire for an enhanced "cooperation and trust" among actors at the border points (Polner, 2011: 56). OSBP, therefore, necessitates information sharing and coordinated actions among agencies working at the border. OSBP imbued the CBM with features such as; close location of offices by relevant states, the establishment of "control zone" where "both states conduct controls in terms of their respective laws" in one territory, seamless transactions conducted by a team of officers from all countries involved and joint underrating of searches and control of cargoes or vehicles (Kieck, 2010: 6-7). The OSBP embraces the concept of extraterritoriality in empowering border officials to apply their country's national law in another country and also operate within the laws of the host country (Kenya Private Sector Alliance, 2010). The Kyoto Convention through its Standards 3.3 supports the OSBP operations by directing that Customs offices at common border points must harmonize their operating hours and competence in facilitating the ease of movements of goods and persons (Polner, 2011: 57). The correlation of competence is very important since it supports the principle of trust which impacts both the safety and security of the countries involved.

In 2009, the EAC Secretariat through the Corridor Development Consultants (CDC) established that the legal instruments in force in the five EAC countries at that time were less supportive of the principles of OSBP (Kenya Private Sector Alliance, 2010). The EAC has developed its framework for the OSBP which has incorporated the single-window approach as a means through which actors in trade and transportation can "lodge standardized information and documents with a single entry point to fulfill all import, export, and transit-related regulatory requirements" (EAC-OSBP, 2016: 7). The Community has called for uniformity in the coordination of the border activities in full compliance with the EAC Act on Border Management (EAC-OSBP, 2016: 22). The Act has provided for a dispute resolution mechanism through an appeal system to the council as the first point of redress and the possibility to use the East African Court of Justice in the event that the Council has failed to handle the matter (EACOSBP, 2016: 26). The identification of the Council as the first point of redress upholds the spirit of 
dialogue in the management of borders as envisioned by the Niamey Convention through Agenda 2063 on seamless border management (Bwire, 2020: 19 May).

Table 1. One-Stop Border Points between EAC countries.

\begin{tabular}{|l|l|}
\hline Common Borderline Countries & Name(s) of OSBP \\
\hline Kenya-Tanzania & $\begin{array}{l}\text { Taveta/Holili } \\
\text { Isebania/Sirari } \\
\text { Namanga/Namanga } \\
\text { LungaLunga/Horohoro }\end{array}$ \\
\hline Kenya-Uganda & $\begin{array}{l}\text { Busia } \\
\text { Malaba }\end{array}$ \\
\hline Tanzania-Uganda & Mutukula \\
\hline Burundi-Rwanda & $\begin{array}{l}\text { Gasenyi/Nemba } \\
\text { Ruhwa } \\
\text { Kanyaru/Akanyaru }\end{array}$ \\
\hline Rwanda-Uganda & $\begin{array}{l}\text { Kagitumba/Mirima Hills } \\
\text { Gatuna/Katuna }\end{array}$ \\
\hline Burundi-Tanzania & $\begin{array}{l}\text { Mugina/Manyovu } \\
\text { Kobero/Kabanga }\end{array}$ \\
\hline Rwanda-Tanzania & Rusumo \\
\hline Uganda-South Sudan & Elegu/Nimule \\
\hline
\end{tabular}

Source OSBP Act, 2016.

\section{Research methodology}

The qualitative research method has been adopted in this particular study. This is because the qualitative research method treats "social life in terms of processes" (Bryman, 2012: 402). A process however has been conceived as "a sequence of individual and collective events, actions, and activities unfolding over time in context" (Pettigrew, 1997: 338). Similarly, it has been averred that "qualitative evidence often conveys a strong sense of change and flux" (Bryman, 2012: 402). The desire to critically assess the behavior of the member states with regard to their commitment to Coordinated Border Management in ensuring free flow of essential goods as transported by truckers within the region informed the choice of this method. The method has enabled a comprehensive evaluation of the events, activities, and measures that were taken by the member states in the management of the pandemic and how that has impacted the cross-border truckers in the region.

The data that has been used in this study has been obtained from both mass media outputs which have been observed as "potential sources for social scientific analysis" (Bryman, 2012: 552). Other documents published by different bodies on the challenges befalling the cross-border truckers as member states implement Covid-19 management measures have also been used as sources of data for this study. Documents as sources of data have been observed as providing "documentary reality" (O'Reilly et al. 2009: 257). Subsequently, Bryman has argued that documents need "to be interrogated and examined in the context of other sources of data" (Bryman, 2012: 551). Taking a cue from this suggestion, this study also incorporated live television interviews especially with key political players like the chair of EAC, President Paul Kagame of Rwanda over the region's response to Covid-19 (Masai, 2020: 1 August). The combination of these different sources has been used in enhancing the validity of the data that has been used in understanding the challenges faced by cross-border truckers in the face of the pandemic despite the existence of the Coordinated Border Management Protocol and the classification of the truckers as essential service providers.

The data obtained has been analyzed using qualitative content analysis. This approach has been observed as the most common approach in "a qualitative analysis of documents" (Bryman, 2012: 557). It entails the search for "underlying themes in the materials being analyzed" (Bryman, 2012: 557). The fact that documents have been the key sources of data in this study makes qualitative content analysis 
an appropriate method of data analysis. Similarly, this method allows for "constant discovery and constant comparison" in search of nuances within the cases under review (Altheide, 1996: 16). This has enabled this study to develop themes around the management of Covid-19 by member states and the implication on cross-border truck drivers. Further, the concept of Coordinated Border Management (CBM) and its key elements like the One-Stop-Border approach has been used as a conceptual framework in understanding the place of restricted cross-border movements during a pandemic and the need to facilitate movements of essential goods and services. The conceptual framework has offered insights on areas of improvement in managing future cross-border movements in an event of a pandemic of this magnitude.

\section{Results and discussions}

The results of the findings have been organized into two broad categories. The first category has presented the member state responses and the new border directives. Under this category are the measures that were taken by different states in the containment of the spread of Covid-19 especially from outside their borders thus, the border restriction measures that would directly affect the crossborder truckers. The second category presents the results on the implementation of the Covid-19 containment measures by the member states and their implication to the cross-border truckers as well as the attended challenges. The findings in this category have been presented in themes and discussed in highlighting the challenges and how they impacted the cross-border truckers as countries grappled with the balance of containing the spread of Covid-19 as well as maintenance of the free flow of essential goods within the region.

\subsection{State responses and new border directives}

EAC member countries responded differently with regard to the containment of Covid-19 which had significant implications on border management and OSBPs. Kenya, for instance, restricted movements in and out of her territory with regard to Tanzania and Somalia on May 16, 2020. This restriction exempted cargo vehicles. This decision followed the earlier restrictions that Kenya had imposed on her border with Uganda on March 23, 2020. In a similar move, Kenya suspended all international flights on March 25, 2020, allowing only those for cargo and repatriation flights to enter or exit the country. This suspension has been in place until August 1, 2020. The move to close down the borders has been considered injurious to different categories of people like the refugees whose "right to seek protection" are curtailed by such border closure measures (MacGregor, 2020: 23 June). Subsequently, Amnesty International through Deprose Muchena made a call for "workable protocols for Covid-19 screening, testing and quarantine" that do not offend both international laws on refugees and human rights (MacGregor, 2020: 23 June). Similarly, the importance of regional integration has been pointed to as a facilitator in the transportation and distribution of essential medical supplies and food items in responding to Covid-19 (Gbenga, 2020: 28 April).

The EAC member countries cognizant of the need to maintain the flow of essential supplies despite the restricted cross-border movements classified the trans-border truck drivers as essential service providers who would be allowed to cross the border on having tested negative for Covid-19. The member states agreed to a double testing strategy where the truckers had to be tested at the point of departure and be retested at the border points in ensuring that truckers do not aid in the spread of the virus. The double testing strategy received a node from four heads of the state comprising of Yoweri Museveni, Uhuru Kenyatta, Paul Kagame, and Salva Kiir of Uganda, Kenya, Rwanda, and South Sudan respectively. The leaders agreed that truckers could drive through the East African region as long as they were negative and called for the adoption of "a harmonized system for certifying and sharing Covid-19 test results and other information" (Nambi and Chombo, 2020: 21 May).

These came on the backdrop of a call for "a well-coordinated and harmonized response, in line with the provisions of the EAC Common Market Protocols and to ensure that there is the availability of essential goods and services in the region" by the EAC secretariat (Covid-19 Plan, 2020: 8). The Covid-19 
response plan under the directive EAC/JMHE/Directive/003 envisaged the need for a coordinated working relationship among "the national task forces, EAC Secretariat and EAHRC" in overseeing the implementation of measures put in place to contain the spread of Covid-19 in the region (Covid-19 Plan, 2020: 6). However, the directives did not resolve to establish an umbrella body that would coordinate the responses by the different stakeholders operating at various levels in combating the spread of Covid-19. This proved to be a major gap with regard to the facilitation of the free movements of essential goods and services across the borders of the member states. The Response plan only recognized the significance of the role that is played by staff at the border points in containing the spread of the virus. This left the responsibility of border management largely under the sole management of the member states which responded differently hence the different implications for the trans-border truck drivers and the delivery of essential services.

\subsection{Implementation and challenges for truck drivers}

4.2.1. Delays, harassment, and stigma

The trans-border truckers despite having been classified as essential service providers who would conveniently cross the borders of the EAC countries faced several challenges with the actual implementation of cross-border transportation. The challenges included delays at the borders, harassment by the security forces, and stigma stemming from the drivers' classification as virus carriers or potential carriers both by government agencies and the local communities through which they drop by for essential supplies. Kenyan truck drivers for instance reported that they were being harassed by Uganda police officers which undermined their safety. This led to a truck drivers' strike at the Malaba border that resulted in a long queue of trucks that paralyzed transport along the border region. This impasse roped in the Kenya Truckers Union with their Secretary-general, Nicholas Mbugua lamenting the absence of a "safety agreement between Kenya and Uganda" with regard to truck drivers during the lockdown (Anami, 2020: 30 May). Mbugua pointed out the need for an expedited agreement on the safety of truck drivers whom he observed were undergoing "unbearable humiliation" in Uganda (Anami, 2020: 30 May).

The challenge that truck drivers were facing also stemmed from testing and acceptance of the testing results. The Ministry of Transport in Kenya issued a directive that required the truck drivers to get the Covid-19 test certificate 48 hours before they commence their journey from Mombasa or enter Kenya from other EAC countries (Nambi and Chombo, 2020: 21 May). The first, challenge with testing was the failure of Ugandan and Kenyan officials to accept the results from each other. Subsequently, in the bid to resolve the issue over the acceptance of the test results, officials from Kenya and Uganda met on May 26, 2020, and agreed to accept the results of each other as was being presented by the truck drivers (Anami, 2020: 30 May). Solom Kitungu, the principal secretary for Transport in Kenya while commenting after attending a meeting with Ugandan officials over the woes of Kenyan truck drivers indicated that some of the compliance to the double testing protocol on the part of the drivers was partly to blame for the delays occasioned at the border (Anami, 2020: 30 May). The meeting also worked out a safety protocol for truck drivers during the lockdown.

A similar case played at the Kenya and Tanzania border. On May 19, 2020, Kenya reported that it had returned some 180 foreigners who had tested positive for Covid-19 to Tanzania. This sparked accusations of faulty testing being conducted by Kenya as sabotage to Tanzania as a tourist destination country (Nambi and Chombo, 2020: 21 May). The lack of trust in each other's competency was upscaled when 19 Tanzanian Truckers who had tested positive for Covid-19 were denied entry into Kenya on May 20, 2020. This attracted a response from a Tanzanian Commissioner in charge of northern Arusha, Mrisho Gambo who reported that the same drivers who tested positive in Kenya had re-tested negative in Tanzania (Nambi and Chombo, 2020: 21 May). This caused long queues as the commissioner ordered that the truckers had to change over their cargo at the border so that owners of the goods had to collect them from the border point denying all truckers from Kenya entry into Tanzania and also suspending the travel of Tanzanian truckers into and through Kenya. 
The stringent controls at the borders caused huge delays in the delivery of goods across the borders within the East African Community. The three to four hours that truckers used for clearance have now turned into three to four days at the Malaba border due to measures put in place to contain Covid-19 (Mkina, Kimono, and Danga, 2020: 1 June). Similarly, the trip from Mombasa to Kampala which usually takes seven days currently takes 12 days due to border procedures and restrictions (Mkina, Kimono, and Danga, 2020: 1 June). The delays occasioned by these measures have reduced the clearance of essential merchandise to less than 50 percent. This "Lengthy Turn Around Times" (TAT) has had negative financial impacts on truckers and the business community at large hindering their ability to meet their financial obligations like loan repayments (Bwire, 2020: 19 May). The case of Khamis Makaranga one of the 19 truckers who were returned to Tanzania after testing positive for coronavirus is insightful since he was transporting tomatoes which are highly perishable from Iringo to Nairobi but had to wait for over seven days to get his test results (Bearak and Ombuor, 2020: 22 May). The consequence was the loss of the tomatoes and an increase in the prices of vegetable products in Kenya due to a decline in supply.

The increase in the cost of goods due to delays presented multiple dangers in the management of the pandemic. For instance, the significance of proper nutrition in the fight against the pandemic has been pointed to by Dr. Matshidiso Moeti of World Health Organization- Africa Regional Office- during the World Economic Forum with a warning that the unnecessary trans-border delays, threatened to worsen the food insecurity in Africa which was already at a precarious level (Nambi and Chombo, 2020: 21 May). In a similar vein, a Kenyan truck driver reported that he had stayed at the border for five days while his other colleagues had stayed there for over ten days pointing to poor health services with understaffed facilities at the Kenyan-Uganda border hence the delays (Wasike, 2020: 17 May). The consequence of which is undersupplied of essential goods which would lead to an increase in prices for such commodities in the region. The Rwandese government policy that imposed a fine of 500 US dollars on drivers who insisted on driving through Rwanda to deliver goods if they could not hand over their trucks to the Rwandese drivers served to increase the cost of goods since such costs are always passed to the consumers (Wasike, 2020: 17 May). These would serve to complicate the food security situation and the fight against the pandemic.

\subsubsection{Relay driving}

The desire to maintain the flow in the supply chain while containing the spread of Covid-19 led to attempts to institute relay driving of trans-border trucks within the EAC. This stemmed from the fact that truck drivers have been viewed as high-risk carriers of Covid-19. The Kigali government for instance preferred that truckers would drive to their border and hand over their trucks to the Rwandan drivers or offload their goods onto trucks managed by Rwandese for delivery to the final destinations within Rwanda (Nambi and Chombo, 2020: 21 May). The disagreement over the relay driving especially between Rwanda and Tanzania led to a stalemate that necessitated an accelerated agreement between the two governments who agreed to lift the relay driving requirement. On May 15, 2020, the government of Rwanda released a statement that indicated that they had agreed on the transfer of merchandise at the border "except for trucks carrying perishable goods and petroleum products destined to Rwanda" (Nambi and Chombo, 2020: 21 May). This move despite solving the immediate impasse created more problems with additional costs of transportation and logistics as well as delays in deliveries.

Kenya and Uganda had a similar case of attempts at relay driving with a changeover of drivers. This decision was informed by the increase in the number of truck drivers who were posting positive results for Covid-19. The Kenyan truck drivers were required to hand over their trucks to Ugandan drivers to deliver the goods to the final destination within Uganda. This prompted Kenya Truckers Association to petition the Ugandan government by pointing out the dangers associated with changeover driving like drivers' responsibility concerning the misuse of trucks and theft of fuel as well as insurance challenges (Gbenga, 2020: 28 April). The insurance companies for instance would contest claims to damages that 
are caused to the truck or theft of merchandise while in the hands of drivers whose information is not with the insurers or their clients. To overcome this impasse, the association proposed mandatory testing at the border such that drivers who would post negative results for Covid-19 would be allowed to proceed on their journey while those with positive results would be isolated and the company allowed to send in another driver to take over the truck after undergoing a test (Gbenga, 2020: 28 April).

The decision to allow truckers who tested negative to continue with their journey has also been imbued with challenges especially stemming from stigma. This stems from the fact that they had been identified as high-risk carriers of Covid-19. For instance, Muhammed Ali, a trucker from Tanzania who was stuck at Mirima Hills in Uganda as he wanted to cross to Rwanda lamented that truckers were being referred to as "corona" despite having posted a negative result for the virus (Nambi and Chombo, 2020: 21 May). Erick Bakari, a Kenyan trucker while narrating his experience in Uganda after having posted negative results for the virus has reported that "we have been denied access to hotels" and the residents "stone us on grounds that we have corona" (Vidija, 2020: 26 May). This was the case with Wasilwa another Kenyan Trucker who pointed out that drivers had limited places to stop for rest because "People point fingers and threaten to stone your truck for fear of spreading Covid-19 to them" (Mkina, Kimono, and Danga, 2020: 1 June). Similarly, Isaac Lumago, a Kenyan trucker on the Mombasa-Juba route lamented over their inability to socialize with the locals who feared them as potential coronavirus carriers (Mkina, Kimono, and Danga, 2020: 1 June).

Ugandan president, Yoweri Museveni in his attempt to address the challenges of stigmatization of truckers by the community advised Ugandans to apply wisdom in dealing with the truckers. $\mathrm{He}$ emphasized that halting cargo transportation would be suicidal by asking the communities to ponder on how Ugandan coffee, tea, cotton, milk, and other products would be transported (Mkina, Kimono, and Danga, 2020: 1 June). The case of stigmatization and fear of the truckers as potential virus carriers is even more complex with regard to the Uganda-South Sudan border. This is because backup drivers and "turn boys" are not permitted in South Sudan which makes the single driver and the truck more vulnerable to cause accidents and attacks (Mkina, Kimono, and Danga, 2020: 1 June). Simon Jamus reports that the $200 \mathrm{~km}$ distance to Juba from the Ugandan border has over 10 illegal checkpoints where one has to pay hefty bribes to pass beside the risk of being robbed the money for upkeep (Mkina, Kimono, and Danga, 2020: 1 June).

\subsubsection{Reduction in the intra-regional trade}

The restriction on the cross-border movements harmed the intra-regional trade. For instance, Kenneth Bagamuhunda who is the EAC Director General of Customs \& Trade indicated that the volume of trade among the members of EAC had plunged and was falling only within the range of 30 to 40 percent in three months compared to what had been there before the outbreak of Covid-19 (The East African, 2020: 29 June). Peter Mathuki who is the chief executive of East African Business Council on his part lamented the fall in the volume of trades in the region by pointing at the reduction in the number of trucks being cleared at the Namanga border from the usual over 3000 trucks to just about 500 due to Covid-19 (The East African, 2020: 29 June). The effect of the fall in volumes of trade and its linkages with restriction of cross-border movements especially of truck drivers led to an increase in the prices of some products since it interfered with the flow of demand and supply. Subsequently, it points to the need for a coordinated approach in handling cross-border issues especially truck drivers and their consignments.

\subsubsection{Loss of job}

Many truckers lost their jobs due to a reduction in the volume of trades as trucks were delayed at the border which reduced income significantly for the owners of the trucks who then would not continue to keep truck drivers on their payrolls. For example, Bob Njagi a truck driver was fired after the goods he was transporting to Kampala-Uganda "had to wait for over two weeks before they could cross to the other side. So, this means there is no business, and we are also out of work" (Yusuf, 2020: 1 June). This 
he observed is occasioned by different kinds of restrictions implemented by different countries which then cause delays in clearing the truck drivers and their consignments (Yusuf, 2020: 1 June). The delays occasioned by understaffing of health facilities which were responsible for the long queues at the borders hence hindering trade attracted non-governmental actors who sought to boost the testing capacity of the governments to help keep the trade flowing. The International Organization for Migration (IOM) for instance partnered with TradeMark East Africa (TMEA) to provide "testing at the borders ... to facilitate the safe continuation of trading activities and especially protecting livelihoods" (IOM, 2020: 24 July).

\subsubsection{Long hours behind the wheels}

Due to stigma and accusations by local community members of being transmitters of the Covid-19 virus, drivers are forced to drive for long distances without taking rest at the usual places where they have taken rest before the pandemic. Felix Juma, a Kenyan truck driver transporting oil to South Sudan reported that "the communities along the routes that we use are attacking us, pelting us with stones whenever we stop to take a rest" (Wasike, 2020: 15 May). This has been complicated by the closure of border points and IOM's Displacement Tracking Matrix, which reported that 50 percent of entry points within the East African Community have been "partially closed due to the pandemic" (IOM, 2020: 24 July). Subsequently, sinking the cargo flow in the Northern Corridor by 30 percent (IOM, 2020: 24 July). The delays in testing, partial closure of over 50 percent of border points confined the truck drivers to long hours behind the wheels and at the same time reduced the volume of cargo flow within the region during the pandemic.

\section{Conclusion}

The EAC member countries should continue to harmonize their health standardization to enable them to enjoy the pursuit and use of OSBP even during pandemics. The harmonization of the health standards would eliminate the suspicion about the validity of the tests conducted by member countries and would ease the requirements for double testing at the borders in facilitating the free flow of essential goods and services. Secondly, there is a need for targeted policy directives that address cross-border management and coordination during emergencies as was occasioned by this pandemic. The EAC secretariat together with relevant ministries needs to design policies that build on the open window framework without abandoning the cross-border management to individual members. The lack of standardization and sound scientific data hurt cross-border management as every member acted in different ways that compromised the uniform implementation of the EAC Covid-19 Plan. Thus, the community needs to establish a joint database and data-sharing platform which would act as the premise upon which policies are drawn for action by member states. Similarly, the community needs to establish a joint testing protocol and training facility specifically dedicated to cross-border surveillance and coordination. This would eliminate the doubting of test results by different partner states and also aid in contact tracing, especially for trans-border truck drivers. Further, this will reduce delays occasioned by understaffing of such facilities since proper needs assessment would be carried out to determine the number of staff needed for the efficient functioning of such facilities. These would combine to enhance efficiency in facilitating movements of essential goods during a pandemic such as this.

\section{Contribution}

The contributions have been organized around the borderless dream within the East African Region as provided by the conceptual framework that has guided this study. The first contribution is that trust of competency levels is critical for the smooth coordination of cross-border movements and operations under the OSBP framework. The OSBP envisions working in harmony and trust based on the agreed level of competency among partners involved at the border. However, the failure to accept test results carried out by member countries pointed to distrust in terms of competency. This led to unnecessary delays and calls for relay driving and offloading of merchandise at the border points. These worked against the very idea of OSBP and may sow bad seeds of distrust even in post-Covid-19 border management. The stringent measures that truckers were exposed to run counter to what had occurred in 
Europe where truckers were exempted from checks at the border. The European case was similar to that of the US and Canada where truckers were also exempted from taking corona tests at the border before crossing (Bearak and Ombuor, 2020: 22 May). The lack of trust among the EAC countries took place even though the members had settled on the parameters to be followed while conducting a test on truckers. The EAC's Deputy Secretary for Planning and Infrastructure, Eng. Steven Mlote confirmed that such agreement had been reached and what was being experienced by the truckers was a question of varying implementation by members (Owaka, 2020: 19 June). This implies that the Community should be able to invest more in the standardization of services across the member countries in the interest of maximizing the advantages of OSBP among the members.

The second contribution points to the need to de-escalate tensions in the interest of the principle of extraterritoriality within the OSBP framework. The tension that characterized the relationship between members with regard to the cross-border management during the Covid-19 pandemic does not auger well with a community that is striving to obtain maximal benefits from OSBP. For instance, the return of 19 truckers who had tested positive for Covid-19 on May 20, 2020, by Kenya to Tanzania escalated tensions that made Kenya close her land border with Tanzania which also threatened to retaliate before a direct involvement of the presidents in toning down the tensions (Mkina, Kimono, and Danga, 2020: 1 June). This move is against OSBP which is based on the concept of extraterritoriality which demands that border management is done jointly with the application of different territorial laws within one territory in facilitating movements of goods and persons. The closure of the border and its threat, therefore, do not serve to promote Coordinated Border Management especially at this time when globalization has led to the fractionalization of production which has stretched the supply chain and for regional leaders of a region gearing towards a single market economy.

Finally, correlation of competency-based on sound data is critical for effective implementation of OSBP. The variance in the implementation matrix for truckers testing for Covid-19 by member countries led to fluctuations in prices due to the destabilization of demand and supply forces within the region. Correlation of competence is essential as per the Kyoto Convention's Standards 3.3 that calls for time and competence coordination in ensuring smooth operation of OSBP. The problem with poor coordination among the EAC member countries in the management of their borders has been identified by the EAC chair and the president of Rwanda, Paul Kagame, as revolving around the inadequacy of "sound public health data" in handling issues (Masai, 2020: 1 August). President Kagame has pointed to the need to integrate scientific data in making decisions and forming opinions away from politics (Masai, 2020: 1 August). This, therefore, buttresses the need for an enhanced competence and its correlation for effective management of borders and pandemics within the community. Subsequently, the community should invest in the standardization of public health practices and equipment to avoid future tensions in the wake of a similar kind of pandemic.

\section{Limitations}

This study is limited to the cross-border management measures put in place by member states of the East African Community. Thus, it is limited to the East African Community Members and does not cover other regions and countries outside the community. The study is also limited in scope to crossborder truckers. It focuses on cross-border truck drivers within the community and does not incorporate those who operate beyond the community's borders. The study is also guided by the principles governing Coordinated Border Management within the purview of One-Stop-Border Post as envisioned by the community. The findings of this study, therefore, need to be appreciated within the guiding principles. This study, therefore, has not delved into the long-standing traditional cross-border relations between individual member states which has the potential of providing different insights into the behavior of the EAC member countries. Further, this study is limited to the management of the Covid19 pandemic hence the understanding of the responses to the pandemic against the borderless dream within the region. 


\section{References}

Altheide, D. L. (1996). Qualitative media analysis. Thousand Oaks, CA: Sage.

Aluga, M. A. (2020). Coronavirus disease 2019 (Covid-19) in Kenya: preparedness, response and transmissibility. Journal of Microbiology, Immunology and Infection.

Anami, L. (2020, 30 May). Kenya, Uganda scramble to resolve Malaba border crisis. The East African. https://allafrica.com/stories/202005300049.html [Accessed, 12. 08. 2020].

Bearak, M. \& and Ombuor, R. (2020, 22 May). At a busy East African border, testing truckers created perfect conditions for coronavirus to spread. The Washington Post. https://www.washingtonpost.com/world/2020/05/22/kenya-tanzania-coronavirusborders/?arc404=true [Accessed, 10. 08. 2020].

Bowman, G. W. (2006). Thinking outside the border: homeland security and the forward deployment of the US border. Houston Law Review, 44 (2): 189-251.

Bryman, A. (2012). Social research methods. New York: Oxford University Press.

Bwire, V. (2020, 19 May). Stop criminalizing truck drivers in war against Covid-19. Capita News. https://www.capitalfm.co.ke/news/2020/05/stop-criminalising-truck-drivers-in-war-againstCovid-19/ [Accessed, 25. 07. 2020].

Doyle, T. (2011). The future of border management. In G. McLinden, E. Fanta, D. Widdowson \& T. Doyle (Eds.). Border management modernization, Washington, DC: IBRD/World Bank.

East African Community. (2016, 15 April). One stop border posts act. Entebbe: Uganda Printing and Publishing Corporation.

EAC Secretariat, (2020, 27 April). East African community Covid-19 response plan. Arusha: East African Community.

Gbenga, A. M. (2020, 28 April). Pandemic threatens relations, cross-border transport of goods in EAC. Venture Africa. http://venturesafrica.com/ugandas-central-bank-threatens-cap-on-bank-interestrates/ [Accessed, 29. 07. 2020].

IOM. (2020, 24 July). Covid-19 testing for truck drivers helps open trade in IOM-TMEA Partnership. International Organization for Migration. https://www.iom.int/news/Covid-19-testing-truckdrivers-helps-open-trade-iom-tmea-partnership. [Accessed, 28.03.2021].

Kabuubi, R. (2020, 2 April). Uganda: respect rights in Covid-19 response. Human Rights Watch. https://www.hrw.org/news/2020/04/02/uganda-respect-rights-Covid-19-response [Accessed, 01. 08. 2020].

Kenya Private Sector Alliance. (2010). OSBP, legal framework for the East African Community. www.kepsa.or.ke/pdfs/EAC_Regional_legal_framework_Jan2010.pdf. [Accessed, 22. 07. 2020].

Kieck, E. (2010). Coordinated border management: unlocking trade opportunities through one-stop border posts. World Customs Journal, 4 (1): 3-13.

MacGregor, M. (2020, 23 June). Covid-19: Rights groups call for African borders to reopen to asylum seekers. InfoMigrants. https://www.infomigrants.net/en/post/25562/Covid-19-rights-groupscall-for-african-borders-to-reopen-to-asylum-seekers [Accessed, 22. 07. 2020].

Maria Nicola, et al., (2020). The socio-economic implications of the coronavirus pandemic (Covid-19): A review. International Journal of Surgery, 78: 185-193.

Masai, M. (2020, 1 August). East Africa should work together to beat Covid-19 says President Paul Kagame. NTV Kenya. https://youtu.be/QiXj1jAafTo

Mkina, S., Kimono, G. and Danga, D. M. (2020, 1 June). On the road with East African truck drivers. Mail \& Guardian. https://mg.co.za/africa/2020-06-01-on-the-road-with-east-african-truckdrivers/ [Accessed, 15. 08. 2020].

Nambi, C. \& Chombo, A. (2020, 21 May). Fear of Covid-19 slows trucking in East Africa. Voanews. https://www.voanews.com/Covid-19-pandemic/fear-Covid-19-slows-trucking-east-africa [Accessed, 29. 07. 2020]. 
Nsanyiwa, D. (2020, 15 April). Tanzania: government and institution measures in response to Covid19. KPMG. https://home.kpmg/xx/en/home/insights/2020/04/tanzania-government-andinstitution-measures-in-response-to-covid.html [Accessed, 05. 08. 2020].

O'dowd, L. (2002). The changing significance of European borders. Regional \& Federal Studies, 12(4), 13-36.

O'Reilly, M., et al. (2009). Doing Accountability: a discourse analysis of research ethics committee letters. Sociology of Health and Illness, 31: 246-61.

Owaka, S. P. (2020, 19 June). Tanzania and Uganda agree on truck drivers' movement amid Covid-19, Arusha: East African Community.

Pettigrew, A. (1997). What is a processual analysis? Scandinavian Journal of Management, 13: 33748.

Polner, M. (2011). Coordinated border management: from theory to practice. World Customs Journal, 5 (2): 49-64.

Tasamba, T. (2020, 22 April). Rwanda uses Ebola experience to combat Covid-19. Anadolu Agency. https://www.aa.com.tr/en/africa/rwanda-uses-ebola-experience-to-combat-Covid-19/1813902 [Accessed, 14. 08. 2020].

The East African. (2020, 29 June). Intra-EAC trade thins as Covid-19 lockdowns restrict movement. https://www.theeastafrican.co.ke/tea/business/intra-eac-trade-thins-as-Covid-19-lockdownsrestrict-movement-1444056 [Accessed, 29. 07. 2020].

Vidija, P. (2020, 26 May). Kenya, Uganda authorities meet to resolve truck drivers standoff. The Star Newspaper. https://www.the-star.co.ke/news/2020-05-26-kenya-uganda-authorities-meet-toresolve-truck-drivers-standoff/ [Accessed, 10. 08. 2020].

Wasike, A. (2020, 17 May). East African truckers face backlash from Covid-19: Residents raise alarm over drivers bringing essential goods, virus across borders. Anadolu Agency. https://www.aa.com.tr/en/africa/east-african-truckers-face-backlash-from-Covid-19/1843735 [Accessed, 17.03.2021].

World Customs Organization (WCO). (2008). Customs in the 21st Century: enhancing growth and development through trade facilitation and border security. Brussels: WCO.

World Customs Organization (WCO). (2009). Background paper to facilitate the discussion on coordinated border management, WCO Inter-Agency Forum on Coordinated Border Management. Brussels: WCO.

Yusuf, M. (2020). Kenya truck drivers lose jobs due to Covid-19 restrictions. Voice of Africa. https://www.voanews.com/Covid-19-pandemic/kenya-truck-drivers-lose-jobs-due-Covid-19restrictions [Accessed, 17.03.2021]. 